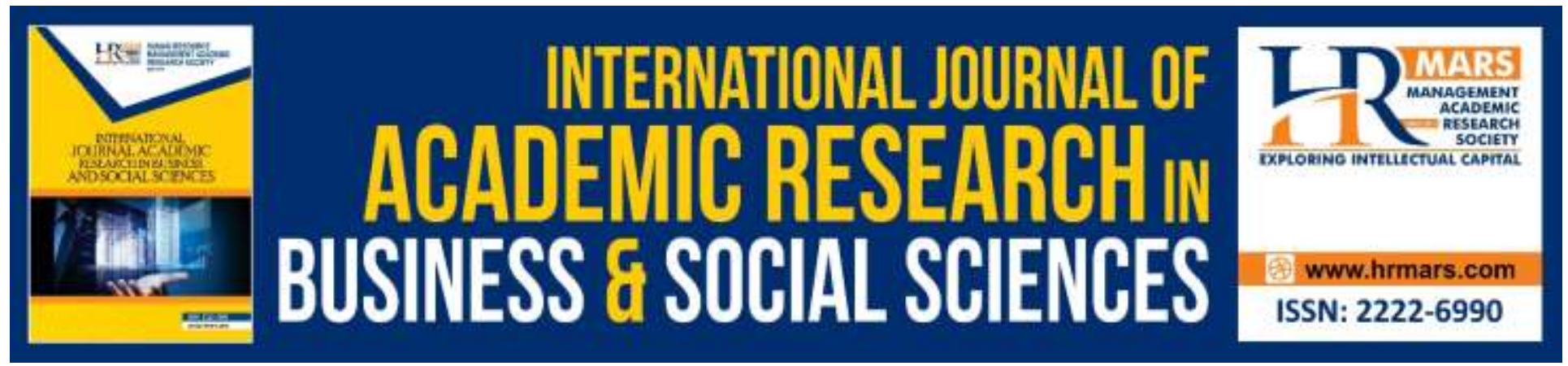

\title{
The al-Ghazali's Soul Therapy Model Based on The Works of al-Arba'in fi Usul al-Din
}

Omar S. H. S., Zin E. I. E. W., Zin, A. D. M., Syuhari M. H. \& Adam N. S.

To Link this Article: $h$ ttp://dx.doi.org/10.6007/JJARBSS/v9-i11/6610 $\quad$ DOI: 10.6007/IJARBSS/v9-i11/6610

Received: 12 October 2019, Revised: 30 October 2019, Accepted: 08 November 2019

Published Online: 28 November 2019

In-Text Citation: (Omar et al, 2019)

To Cite this Article: Omar S. H. S., Zin E. I. E. W., Zin, A. D. M., Syuhari M. H. \& Adam N. S. (2019). The al-Ghazali's Soul Therapy Model Based on The Works of al-Arba'in fi Ușul al-Din. International Journal of Academic Research in Business and Social Sciences, 9(11), 914-920.

Copyright: (C) 2019 The Author(s)

Published by Human Resource Management Academic Research Society (www.hrmars.com)

This article is published under the Creative Commons Attribution (CC BY 4.0) license. Anyone may reproduce, distribute, translate and create derivative works of this article (for both commercial and non-commercial purposes), subject to full attribution to the original publication and authors. The full terms of this license may be seen at: http://creativecommons.org/licences/by/4.0/legalcode

Vol. 9, No. 11, 2019, Pg. 914 - 920

http://hrmars.com/index.php/pages/detail/IJARBSS

JOURNAL HOMEPAGE

Full Terms \& Conditions of access and use can be found at http://hrmars.com/index.php/pages/detail/publication-ethics 


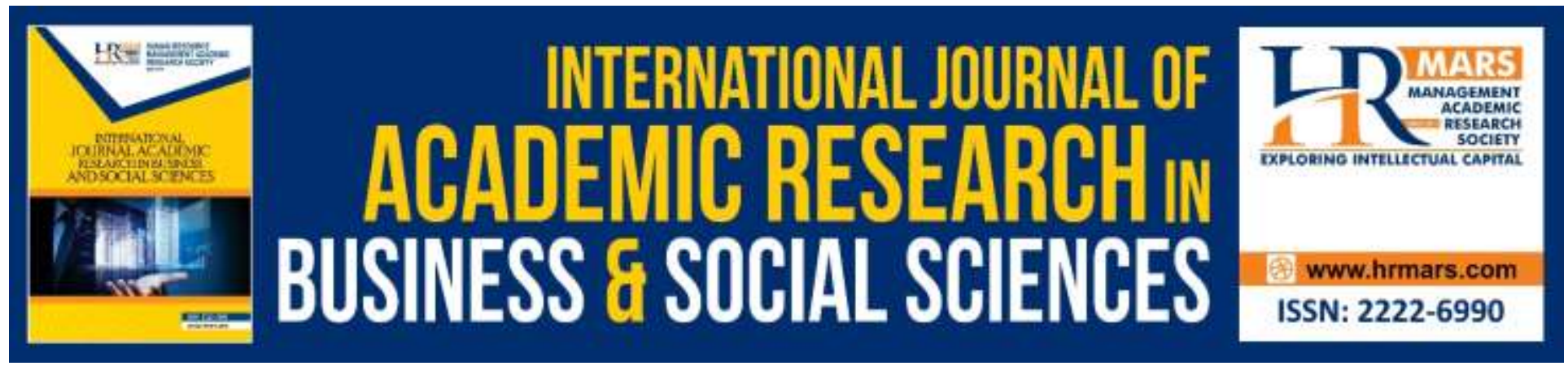

\title{
The al-Ghazali's Soul Therapy Model Based on The Works of al-Arba'in fi Ușul al-Din
}

\author{
Omar S. H. S. ${ }^{1,2}$, Zin E. I. E. W. ${ }^{2}$, Zin, A. D. M. ${ }^{2}$, Syuhari M. H. \& \\ Adam N. S. ${ }^{2}$ \\ ${ }^{1}$ Institute of Islamic Product Research and Islamic Civilization, Universiti Sultan Zainal Abidin, \\ Malaysia, ${ }^{2}$ Faculty of Islamic Contemporary Studies, Universiti Sultan Zainal Abidin (UniSZA), \\ Malaysia \\ Email: sylutfi@unisza.edu.my
}

\begin{abstract}
A great deal of soul therapy is accentuated by researchers to address the crisis that occurs in society, such as music as the messing soul therapy being, besides motivational words are also brought out as a therapeutic substance in addressing the issue. The healing in tackling various diseases such as presumptuous feelings, arrogant, majestic, show off the self-advantages and others that have been highlighted by ancient Islamic scholars are not popular emphasized in scientific studies. The implications of neglect to the survey of the therapeutic relationship of such negative values with the given spirit of the soul therapy, the issue of a moral impact of individuals among the society that will never find a solution. Hence, this qualitative work is conducted to identify how the soul therapy can be brought out through the content analysis method of the spiritual theories presented by a prominent Sufi figure, al-Ghazali (d. $505 \mathrm{H})$. This work developed a Model of the Soul Therapy using the Value chain analysis framework, by loading essential elements of spiritual being theory in his works titled "Al-Arba'in Fi Usul al-Din." His various statements in the therapy process were formulated to be used as a number of the principal activities for soul therapy, while others were supporting activities for the completeness of the primary activity. As a result of the analysis of al-Ghazali's theory, the study entirely built alGhazali's Soul Therapy Model. The study found that the soul therapy model based on Tazkiyah and Tahliyyah methods emphasized by al-Ghazali was able to contribute a positive impression on the individual soul building. Hence the model is practiced among the community, and it will surely develop a society living in harmony, mutual esteem, and tolerance. The study concluded that the concept of the Soul therapy brought out by al-Ghazali, especially practices among the community today in sculpting people with sacred souls.
\end{abstract}

Keywords: Soul Therapy, al-Ghazali, Tazkiyyah al-Nafs, al-Arba'in Fi Ușul al-Din. 


\section{Introduction}

Soul therapy is something indispensable for an individual, as well as in curing disease. According to works of literature, the researchers mostly emphasized their research related to the spiritual model generally without the subject of discussing on the method to deal with it (Zarrina, 2003; Rosmizi, Mihlar, Muhammad et al., 2017; Desfitrina, 2018). Probe on the definition of a soul therapy submitted by former researchers formulated that the soul therapy from Islamic perspectives refers to a method of psychological healing disorders (Razak, Kamal \& Sharazad, 2013). Grounded on verses of Qur'an, and hadith of the Prophet Muhammad in this regard, the concept of the soul therapy or also known with the term Tazkiyyah al-Nafs among the Sufi figures expansively discussed. Among the Sufi figures are al-Hasan al-Basri (M. 110h/738m), Malik Ibn dinars (M. 131h/748m), Ibrahim Bin Adham (M. 161h/779m), has been found to allocate the concept of purification of souls into two portions. Firstly, the sanctified soul of the negative traits (madhmumah), which stands for the redemption of the soul from being bound by what is a human desire. Secondly, the sanctification of the soul by enriching the soul with the commendable attributes (Zarrina, 2003; Weda \& Sakti, 2018).

Consequently, this article is trying to study on a model of al-Ghazali's spiritual theories based on the al-Arba'in fi Ușul al-Din. Al-Ghazali also existed as one of the Sufis, presenting the concept of soul therapy through his works (Al-Ghazali, 1988). Al-Ghazali namely Abu Hamid Muhammad bin Muhammad bin Muhammad al-Ghazali had been born in Ț (the next town in Khurasan after Naisabur) on Dzu al-Qa'idah 450H/1058M. He died in Dawn, Monday on 14 Jamadi al-Finals 505H/18 December 1111M (Al-Ghazali, 1988; Nabil, 2000; Edi, 2011). During his lifetime, al-Ghazali, who was once a trainer at Niżamiyyah had produced many works. Among his works remain Ihya; ' Ulum al-Din, Bidayah al-Hidayah, Tarbiah al-Awlad, al-Arba'in Fi Ușul al-Din and more. The Book of al-Arba'in fi Ușul al-Din has been the preliminary reference for every subject about spiritual elements. A narrated explanation similarly supports it by presenting the basics of the Qur'an and the hadith of the Prophet Muhammad P.B.U.H. as well as providing useful recommendations to be practiced.

\section{Research Methodology}

This article has proposed the view of al-Ghazali founded on heart therapy theory through his work al-Arba'in fi Ușul al-Din. Thus, to obtain related data, the study has used a qualitative study method (Uzayrah, 2016; Othman, 2017) by making the book a significant extension in addition to the journals, articles and related publications (Sabitha, 2005). Then the data obtained is analyzed utilizing the method of content analysis. Side by side, the study has classified collected data in principles based on the objective of the research that has been ascertained, which has then constructed a model of soul therapy.

\section{Discussions and Findings}

This article focuses on a model of soul therapy based on the spiritual theory of al-Ghazali through his work al-Arba'in fi Ușul al-Din. 
The Al-Ghazali's Soul therapy Model

The Model has been used Value Chain Analysis (Porter 1985) framework by loading crucial elements of spiritual theories based on the works of Al-Ghazali titled "Al-Arba'in Fi Usul al-Din." The Model of the structure is perfect to know the primary function and support of each element related to the soul film to achieve targeted goals. However, the model is usually practiced in the financial field to accomplish a possible level of profit that might (Kristina, 2018).

In this book, there are four main parts of the present by Al-Ghazali. The first part contains ten crucial principles of belief in God. The second part contains ten foundations of physically worships. The third part of Al-Ghazali has loaded the ten main properties (madhmumah), which are the basis for the emergence of various other adverse properties. Finally, in the fourth part, he describes the ten essential principles of the commendable nature (mahmudah) that it needs to be held by one who wishes to achieve its moral perfection.

In the first part, which is the faith of the oneness of God, al-Ghazali has explained the foundation of faith in transcendence and declaring incomparability of God, the power of God, the knowledge of God, the God's need, hearing, visual, Kalam, act of God, Afterlife and prophetic. While in the second part, al-Ghazali has elaborate on the physically worship such as Prayer, Zakat and charity, fasting, Hajj, reading al-Quran, Dhikr, seeking halal, fulfilling Muslim rights, telling goodness and removing evil, and according to the Sunni brought by the Prophet Muhammad PBUH.

In this third part of the book of al-Arba'in fi Ușul al-Din, al-Ghazali has elucidated on the evil attributes (madhmumah) that compelled to be wiped off from the soul. These traits are greedy (sharah al-akl), greed speaks a lot (sharah al-kalam), angry (ghadab), jealous (hasad), scrimp and stingy (bukhl \& hubb al-mal), pride love (hubb al-jah), world love (hubb al-dunya), arrogant (takabbur), self-proud ('ujub), and riyak (which means perform worship with the purpose of show off to the public). The fourth part of the last section, Al-Ghazali discussed the Commendable properties (Mahmudah) that decorate the soul after successfully purifying the evil attributes off the soul. The attributes of the Mahmudah are repentant (tawbah), fear (khawf), trifle (zuhd), patience (sabr), gratitude (shukr), sincere and genuine (ikhlas \& sidq), submission (tawakkul), love (hubb), contentment (rida) and death recall (dhikr al-mawt) (Al-Ghazali, 2003). As a result of the analysis of al-Ghazali's spiritual theories based on the work, the study has entirely built a Model of the Soul Therapy.

Broad range statements were in the process of soul therapy through al-Ghazali's works al-Arba'in fi Ușul al-Din was formulated as a model. In the model, it has two activities that play an essential role in completing the soul therapy process, namely primary activities and secondary activities. Elements in the primary activities of the model are the ten evil traits (madhmumah) that need to be wiped off the soul and ten noble traits (mahmudah) that must illuminate the soul. The primary activity is a significant focus in the construction of this model.

Nevertheless, primary activities demand support activities achieve al-Ghazali's Model construction goals. The support activity on this model consists of ten faiths of God and the ten of physically worships. Support activities are also not less essential to complete the primary activity. 
INTERNATIONAL JOURNAL OF ACADEMIC RESEARCH IN BUSINESS AND SOCIAL SCIENCES Vol. 9, No. 11, November, 2019, E-ISSN: 2222-6990 @ 2019 HRMARS

The Al-Ghazali's Soul Therapy Model According to His Spiritual Theory PRIMARY ACTIVITIES

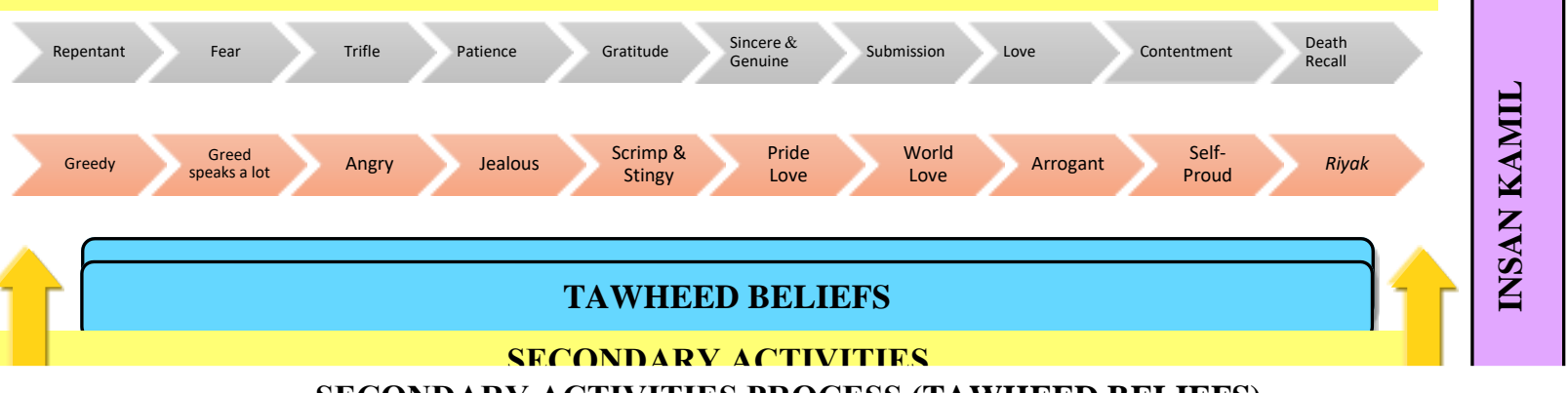
SECONDARY ACTIVITIES PROCESS (TAWHEED BELIEFS)

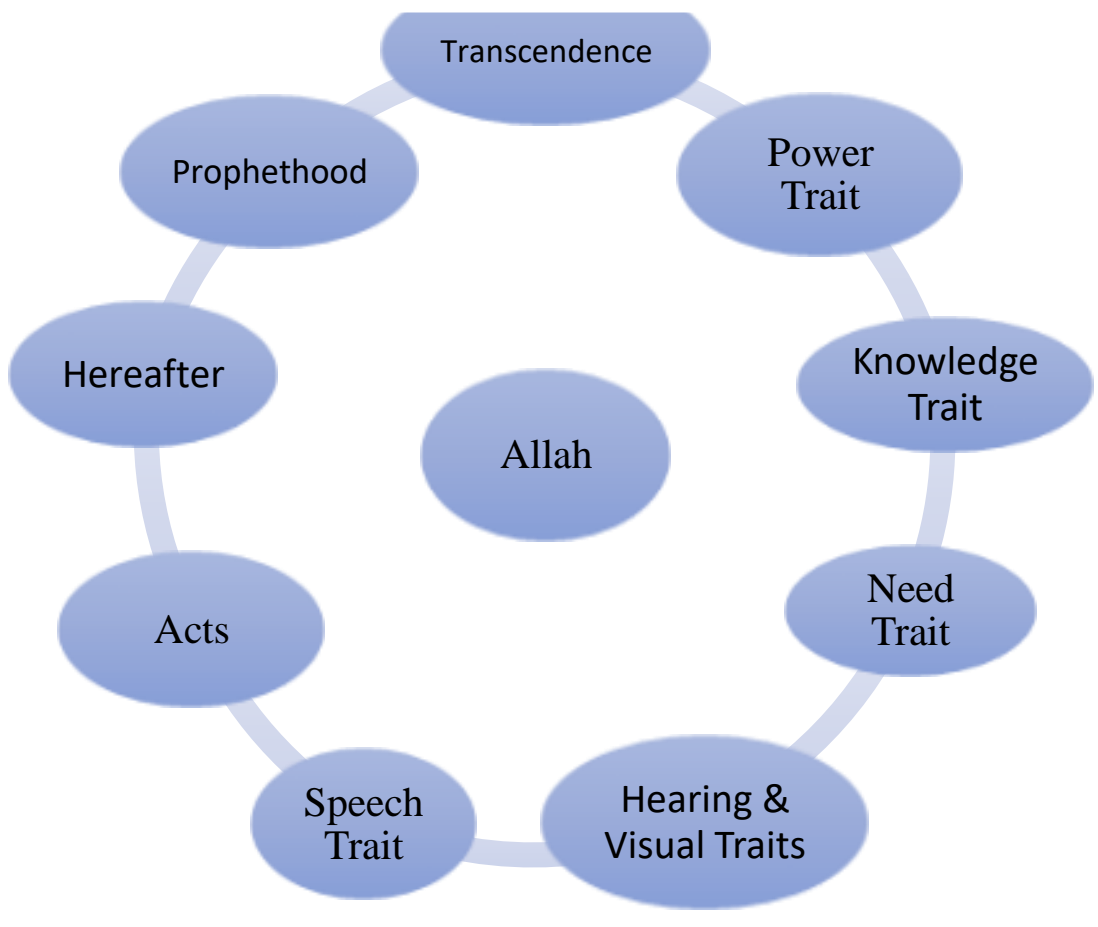




\section{SECONDARY ACTIVITIES PROCESS (PHYSICALLY WORSHIPS)}

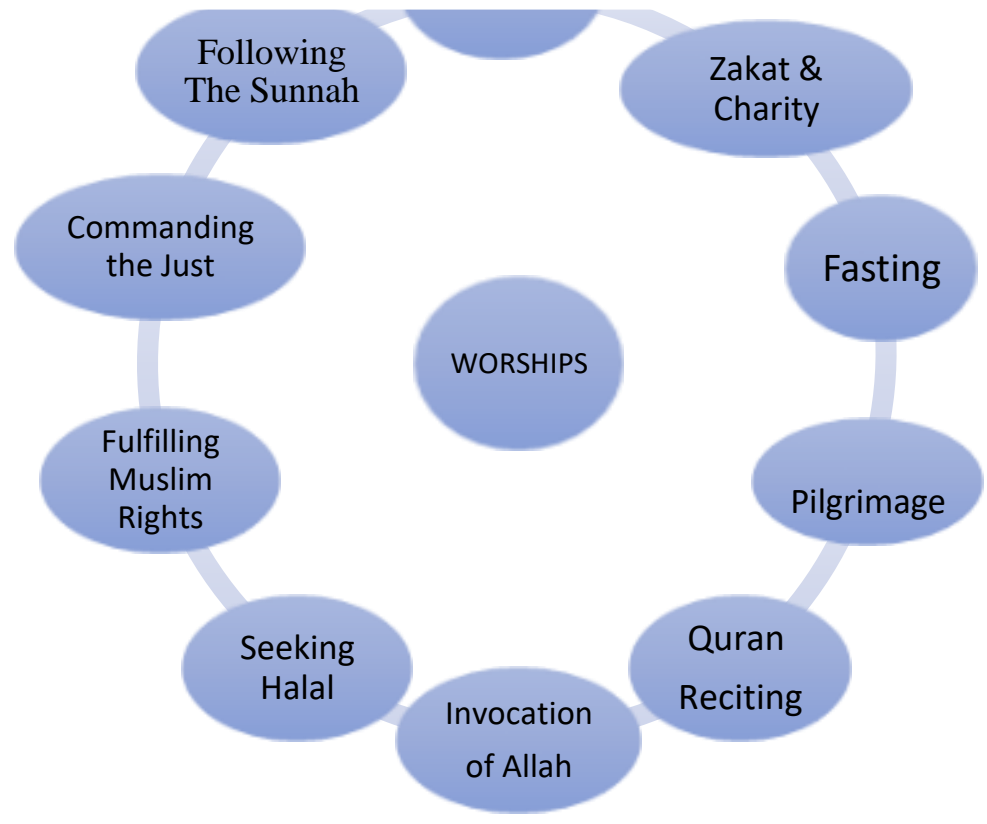

\section{Conclusion}

The concept of Soul therapy has been long discussed by previous Sufi figures such as al-Ghazali by using the term Tazkiyah al-Nafs. Because of having a sparkling soul highly demanded in Islam, al-Ghazali has written a work titled Al-Arba'in fi Ușul al-Din. Based on the analysis of the works, a model of soul therapy based on the theory of al-Ghazali has been developed to address the humanitarian crisis. Hence, the study hopes that this model can produce individuals who use it in the soul education session, to be applied to them a fundamental idea of the Quranic value that is concluded in the spiritual theory of Ghazali applied in the al-Ghazali's Soul Therapy Model. It is the faith Oneness of Allah, the oneness characteristics of Allah and the oneness Acts of Allah. Their understanding of these three aspects of the field would enable them to experience the instructions contained in the Qur'an well and entirely.

\section{Acknowledgement}

This article is part of a research sponsored by the Center for Research and Innovation (RMIC), Sultan Zainal Abidin University (UniSZA), Gong Badak Campus 21300 Kuala Nerus, Terengganu, Malaysia.

\section{References}

Al-Ghazali, A. H. (1988). Ihya' 'Ulum Al-Din. Kaherah: Markaz Al-Ihtiram Li Al-Tarjamah Wa AlNasyr.

Al-Ghazali, A. H. (2003). Al-Arba'in Fi Usul Al-Din. Damsyiq: Dar Qalam. 
Desfitrina. (2018). The Influence, Gender, Life on Development Planning in Indonesia, International Journal of Academic Research in Accounting, Finance and Management Sciences 8 (3): 255-264.

Razak, Mokhtar \& Sulaiman,. (Vol. 14, No. 1, Juni 2013). Terapi Spiritual Islami Suatu Model Penanggulangan Gangguan Depresi. Jurnal Dakwah Tabligh, 141- 151.

Sa'ari, C. Z. (2003). Purification Of Soul According To Sufis: A Study Of Ghazali's Theory. Jurnal Afkar, 95- 112.

Zucchi, K. (2018). Investopedia. Retrieved Jul 25, 2019, From Https://Www.Investopedia.Com

Rahman, M. R., Muthaliff, M., Mahyuddin, M. K., Mokhtar, A. N. \& Ahmad, Y. (2017). A Spiritual Model Of Good Deeds According To Imam Al-Ghazali. International Journal Of Business And Social Science, 181- 189.

Kurnanto, M. E. (2011). Pendidikan Dalam Pemikiran Al-Ghazali. Jurnal Khatulistiwa, 161- 176.

Lebar, O. (2017). Kajian Kualitatif. Tanjong Malim: Universiti Pendidikan Sultan Idris.

Marican, S. (2005). Kaedah Penyelidikan Sains Sosial. Selangor: Prentice Hall/ Pearson Malaysia.

Tobi, S. U. (2016). Qualitative Research, Interview Analysis And Nvivo 11 Exploration. Kuala Lumpur : Aras Publisher.

Weda, S., \& Sakti, A. E. F. (2018). Formal Instruction and Its Effects on the Acquisition of English Affricate Consonants. International Journal of Academic Research in Progressive Education and Development, 7(3), 1-13. 